\section{A kora avar lándzsák tipológiája}

\author{
CSIKY GERGELY*
}

A szerző a kora avar kori lándzsákat osztályozza, foglalkozik azok elterjedésével és tipológiai fejlödésével. E kérdések vizsgálata mellett kitér egyes kronológiai kérdésekre és a kora avar kori lándzsacsúcsok kapcsolatrendszerével kulturális problémákra.

\section{Bevezetés}

A kora avar kori fegyverek és ezen belül a lándzsák kutatása nagy múltra tekint vissza, hiszen az első az avarokhoz kötött tárgyak ${ }^{1}$ közé tartoztak a nádlevél alakú kopják. ${ }^{2}$ A lándzsák kutatása a továbbiakban is megtartotta kiemelt szerepét, annál meglepőbb ugyanakkor, hogy összefoglaló rendszerezésük nem készült el.

A kora avar kori lándzsák nagy száma (gyüjtésem jelenlegi állapota szerint 264 darab) azt mutatja, hogy fontos szerepet töltött be a közelharci fegyverek között a kora avar korban, bár elterjedésükben feltünő aránytalanság figyelhető meg a Dunántúl javára. ${ }^{3}$

\footnotetext{
* Csiky Gergely, ELTE-BTK Régészettudományi Intézet H-1088 Budapest Múzeum krt. 4/B

${ }^{1}$ PULSZKY 1874, 1-12; a sír kutatástörténetéhez lásd BÓNA 1982-83, 98-104.

${ }^{2}$ A nádlevél alak elnevezést először Hampel József használta: HAMPEL 1905, I. 179-182.

${ }^{3}$ A kora avar kori lándzsacsúcsok lelőhely szerinti megoszlása alapján azok $51 \%$-a, míg darabszám szerinti megoszlásban 80\%-uk a Dunántúlról került elö.
}

Jelen dolgozatomban a kora avar kori ${ }^{4}$ lándzsák osztályozásával és tipológiájával foglalkozom, így nem érintem a lándzsák funciójával és társadalomtörténeti jelentőségével kapcsolatos problémákat.

\section{Kutatástörténet}

$\mathrm{Az}$ első avarokhoz kötött lándzsacsúcs Szentendre-Pannónia dülői 1. sírból került elö. $^{5} \quad$ Viszonylag korán kialakult a lándzsákkal kapcsolatos terminológia is, Hampel József hasonlította a keskeny lándzsacsúcsok pengéjét a nádlevél alakjához, melyeket kopjának (Spieß) határozott meg. ${ }^{6}$

Csallány Dezső munkássága a kutatásban még mindig érezteti a hatását. Ö fejtette ki először az áldozati máglyalelet elméletét a Szeged-csengelei, ${ }^{7}$ majd a bácsújfalusi lelettel kapcsolatban. ${ }^{8}$ Csallány gyüjtötte össze a rácsmintás gyürükkel díszített nádlevél alakú kopjákat, melyek értelmezése szerint a kuturgur-bolgárok (vagy kutrigurok) régészeti hagyatékát képezik, hiszen az általa avarként meghatározott - tiszántúli fülkesíros népességnél nem fordulnak elö. ${ }^{9}$

A kutrigur-elmélet tarthatatlansága már a tanulmány megjelenésekor nyilvánvaló volt. Részben az erre adott egyik válaszreakció volt Kovrig Ilona tanulmányának megjelenése, melyben az avarság legkorábbi hagyatékának meghatározásakor éppen ezt - a Csallány által kutrigurként értelmezett leletanyagot vette alapul. Az áldozatadás szokását belső-ázsiaiként értelmezte, a korai lándzsacsúcsok egy részének jó

\footnotetext{
${ }^{4}$ A továbbiakban Falko Daim (DAIM 1987, 159), Max Martin (MARTIN 1989, 74.) és Vida Tivadar (VIDA 1999, 193-194.) meghatározásával egyetértve a kora avar kor végét 650 körüli időpontra teszem.

${ }^{5}$ PULSZKY 1874, 1-12; a sír kutatástörténetéhez lásd BÓNA 1982-83, 98-104.

${ }^{6}$ HAMPEL 1905, I. 179-182.

${ }^{7}$ CSALLÁNY 1939, 9.

${ }^{8}$ CSALLÁNY 1953, 133-137

${ }^{9}$ CSALLÁNY 1953, 133-137
} 
minőségét pedig a türkök korabeli magas szintü vaskohászatával magyarázta. Már ő felfigyelt a leletanyag dunántúli sürüsödésére, szerinte a leletek a római úthálózathoz igazodtak. ${ }^{10}$

$\mathrm{Az}$ avar kori lándzsák első összefoglalását Kiss Attila végezte el szakdolgozata keretében, melyben már nem csak a nádlevél alakú kopjákkal, hanem a levél alakú pengéjü lándzsákkal is foglalkozott. A kopja és lándzsa szavak használatában némi terminológiai bizonytalanság tünik fel: a kopjákat hajítófegyverként határozta meg, ${ }^{11}$ holott az valójában döfőfegyvert jelent. ${ }^{12}$

$\mathrm{Az}$ avar kori lándzsák kutatása a délnémet meroving kori kutatásokban is visszhangra talált: Ursula Koch a Regensburg környéki leletek feldolgozásakor a keskeny, nádlevél alakú pengéjü lándzsacsúcsokat avar eredetünek határozta meg, és jelentős avar hatásokkal számolt a VI. század végi és VII. század eleji bajorországi, alemann és itáliai langobard leletanyagban. A keskeny nádlevél alakú lándzsacsúcsokat négy típusra osztotta: az Untermassing-típus Dél-Bajorországra, a Steinheim-típus Baden-Württembergre, a Nocera Umbratípus Itáliára végül a Szentendre-típus a Kárpát-medencére jellemző. ${ }^{13}$

Először a környei temetővel kapcsolatban figyelt fel a kutatás a meroving kulturális kapcsolatrendszerrel rendelkező lándzsákra. ${ }^{14} \mathrm{~A}$ temetőt publikálói tévesen a VI. század első felére keltezték, és a különféle eredetü tárgyakat azzal magyarázták, hogy a temető egy etnikailag heterogén bizánci zsoldos-csapat nyughelye lehetett. ${ }^{15} \mathrm{Az}$ elmélet és a

\footnotetext{
${ }^{10}$ KOVRIG 1955a, 30-44.

${ }^{11}$ KISS 1962, 93-96.

${ }^{12}$ A továbbiakban az ehhez hasonló terminológiai zavar elkerülése végett nem használom a kopja, a dárda és a döfölándzsa kifejezéseket, melyek már egy funkcionális elkülönítésre utalnak, helyettük egységesen a lándzsacsúcs szót alkalmazom.

${ }^{13}$ KOCH 1968, 89-91.

${ }^{14}$ SALAMON - ERDÉLYI 1971, 56-57.

${ }^{15}$ SALAMON - ERDÉLYI 1971, 70-71.
}

datálás tarthatatlanságára Tomka Péter már 1973-ban helyesen rámutatott. ${ }^{16}$

Az avar nehézlovasság fegyverzetének bizánci és nyugati párhuzamaira először Joachim Werner hívta fel a figyelmet az Isola Rizza-i ezüsttál ábrázolásával kapcsolatban. $^{17}$ A kora avar kori nehézlovas harcmodor keleti kapcsolataival Bóna István foglalkozott a Szegvár-sápoldali sír kapcsán. A döfölándzsákat és az ehhez kapcsolódó harcmodor nyomait keleten egészen Koreáig követte. ${ }^{18}$ A belső-ázsiai párhuzamok kutatása a továbbiakban is folytatódott a Biharkeresztes-lencsésháti sír fegyvereivel kapcsolatban, ${ }^{19}$ ugyanakkor a kora avar kori fegyverzet nyugati és mediterrán kapcsolataira nem fordítottak kellő figyelmet.

Az így kialakult képet Uta von Freeden módosította, aki megfordította az Ursula Kochnál $^{20}$ leírt kulturális kapcsolatok irányát, és jelentős bizánci hatásokkal számolt a kora avar kori fegyverzetben. Tanulmányában felvetette a keskeny, nádlevél alakú lándzsacsúcsok bizánci eredetét, és jelentősen kibővítette Koch gyüjtését az itáliai és dél-németországi kopjákról. $^{21}$ Valószínűleg az igazság valahol a két elmélet között lehet, és egyirányú hatások helyett inkább kölcsönhatásokra gondolhatunk a bizánci és avar fegyverzet között. ${ }^{22}$

A meroving fegyverzetre gyakorolt avar hatásokról legutóbb Mechtild SchulzeDörlamm értekezett, aki ezzel kapcsolatban felvetette az itáliai langobard

\footnotetext{
16 TOMKA 1973, 227-231.

${ }^{17}$ WERNER 1971, 110-111.

${ }^{18}$ BÓNA 1980, 47-48.

${ }^{19}$ MESTERHÁZY 1987, 222-225.

${ }^{20}$ KOCH 1968, 89-91.

${ }^{21}$ von FREEDEN 1991, 610-623.

${ }^{22}$ A bizánci hadseregben ebben a korszakban változik meg a döfölándzsa elnevezése kontos-ról kontarionra (KOLIAS 1988, 191-192), elterjed egy újfajta páncélzat a zaba (KOLIAS 1988, 37-38.), és megjelenik a kengyel (Maurikios I. 2.: DENNIS GAMILLSCHEG 1981, 81; Maurikios II. 9.: DENNIS - GAMILLSCHEG 1981, 129.). Ezek a párhuzamos jelenségek a bizánci nehézlovas fegyvernemen belüli változásokra utalnak.
} 
közvetítés lehetőségét. Felhívta a figyelmet arra, hogy bár a nehézlovasságra jellemző döfölándzsák viszonylag gyakran bekerülnek dél-németországi meroving sírokba is, a fegyverkombinációk alapján mégis a már megszokott gyalogos közelharci taktikájukhoz alkalmazták azokat. $^{23}$

$\mathrm{Az}$ avar kori fegyveres sírok társadalmi értelmezése kapcsán Szentpéteri József teljes gyüjtést készített a lándzsacsúcsokról, és foglalkozott elterjedésükkel és társadalmi jelentésükkel. Megállapításai szerint a kora avar korban a lándzsák a Duna és a Tisza folyók mentén csoportosulnak, és különösen nagy számban fordulnak elő a Dunántúlon, míg a Tiszántúlon kifejezetten ritka leletnek számítanak. $^{24}$

A kora avar kori lándzsákat elsőként a pókaszepetki temető lándzsaleleteivel kapcsolatban Cs. Sós Ágnes és Salamon Ágnes rendszerezte. A lándzsákat formájuk alapján négy csoportba (I-IV.) osztották, és ezeken belül méret szerint (A1-2) és a köpü- és pengehossz arányai szerint (B1-2) különítettek el az egyes típusokat. ${ }^{25}$ A fenti osztályozás problémája, hogy a nagy csoportok (I-IV.) elkülönítésénél nem egy egyértelmü kritériumot választottak ki, és így eltérő jellegzetességeket (Merkmal) hasonlítottak össze.

Garam Éva a tiszafüredi temető elemzése kapcsán rendszerezte a lándzsacsúcsokat. Típusai a következők: 1 . keskeny pengéjü és rombusz átmetszetü lándzsák, 2. tollhegy-formájú lándzsa (Federspitzenförmige Lanzen), 3. nádlevél alakú lándzsák, 4. hosszú, elkeskenyedő köpűböl álló lándzsák, 5. egyedi típus, 6 . kis méretü nádlevél alakú lándzsa. ${ }^{26} \mathrm{Az}$ osztályozás fó kritériuma a penge formája volt, egy esetben azonban a lándzsa mérete.

\footnotetext{
${ }^{23}$ SCHULZE-DÖRRLAMM 2006, 493-494.

${ }^{24}$ SZENTPÉTERI 1993, 186-189. Az elterjedésre vonatkozó vizsgálataiban a lelőhely szerinti megoszlást vette alapul.

${ }^{25}$ SÓS - SALAMON 1995, 67-69.

${ }^{26}$ GARAM 1995, 349-350.
}

Kiss Attila a Kölked-A temető monográfiájában írta meg lándzsatipológiáját. Ö négy típust és egy egyedi esetet (Sonderform) különböztetett meg. A négy típus a következö: páncéltörő, füzfalevél alakú, keskenypengéjü lándzsák és extra-keskeny pengéjü lándzsák. ${ }^{27} \mathrm{Az}$ általa leírt első három típus megfeleltethető a későbbiekben leírt I. csoportnak és III/1 és III/2. típusoknak. Nézetem szerint az extra-keskeny pengéjü lándzsák elkülönítése indokolatlan.

A fent leírt rendszerezések egy-egy temető lándzsaleleteinek osztályozásával készültek, így a viszonylag kis darabszám eleve korlátozta lehetőségeiket.

\section{A kora avar kori lándzsacsúcsok osztályozásának módszere}

A kora avar kori lándzsák felosztásánál Hans Jürgen Eggert rendszerét követve elkülönítem az osztályozást (Klassifikation), melyen az egyes tárgyak formai csoportosítását értem, és a tipológiát, mely az egyes típusok közötti fejlödési sorokat hivatott megrajzolni. ${ }^{28} \mathrm{~A}$ lándzsacsúcsok felosztásának alapját az ún. kombinációs típusok képezik, melyek több kritérium együttes vizsgálatán alapulnak. A lándzsák pengeformáját tekintem fökritériumnak (Hauptmerkmal), ${ }^{29}$ a többit másodlagosnak. A fö kritérium vizsgálata nyomán létrejött formacsoportokat (Formengruppe) a szerint választom szét típusokra, hogy melyik másodlagos kritérium mutat jellegzetes mintázatot. A másodlagos kritériumok közé tartozik a penge átmetszete, a lándzsa penge- és köpűhosszának aránya, a lándzsacsúcsok méretei, a köpü kiképzése és a lándzsacsúcsok díszítése. A

\footnotetext{
${ }^{27}$ KISS 1996, 234.

${ }^{28}$ EGGERT 2005, 122-133. A tipológiai módszer alapelveiről EGGERT 2005, 186-194. A kérdés kutatástörténeti hátteréről KLEJN 1983, 1.

${ }^{29}$ A ,Merkmal”-fogalomról EGGERT 2005, 128133.
} 
lándzsacsúcsok részeit és föbb méretadataikat az 1. kép ábrázolja.

A penge formája alapján négy fó csoportra oszthatók a lándzsák: I. keskeny, nádlevél alakú, II. kúpos, kihegyesedő, III. levél alakú és IV. levél alakú középbordás.

A penge- és a köpűhossz aránya alapján három csoportot különíthetünk el: 1) a penge és a köpü hossza nagyjából megegyezik, 2) a penge hosszabb, mint a köpü, 3) a köpü hosszabb, mint a penge.

A köpü kiképzése alapján öt csoport különíthető el: a) nyitott köpü, b) kapoccsal összefogott nyitott köpü, c) zárt köpü, d) összekalapált köpüszárnyak, e) szorosan egymás mellé hajlított köpüszárnyak.

A továbbiakban a formacsoportokat római számmal, ezen belül a típusokat arab számmal, a variánsokat pedig kis betüvel jelölöm.

\section{Keskeny, nádlevél alakú lándzsacsúcsok}

E lándzsacsúcsok általános jellemzője, hogy pengéjűk keskeny, az élek egymással párhuzamosan futnak, és legtöbbször tompaszögü hegyben találkoznak össze. A penge és a köpü között nyak figyelhető meg, e nélkül elnevezése nem nádlevél alakú, hanem elkeskenyedő, kúpos lándzsacsúcs lenne. Esetenként a penge és a nyak között egy éles válltörés figyelhető meg, néhány esetben a penge alsó részén hatszögletü kötőtag (Zwischenfutter) ${ }^{30}$ található. A kötőtag utánzása jóval gyakoribb, ekkor a penge alsó részén egy kis peremet alakítanak ki. A köpü felső és alsó peremét esetenként rácsmintás gyürükkel erösítették meg, de e helyett előfordulhat bordázott gyürü is. A keskeny, nádlevél alakú lándzsacsúcsok legtöbbször nyitott köpüsek, de elöfordulnak zárt köpüs példányok is. (2. kép)

\footnotetext{
${ }^{30}$ A fogalom használatára lásd FREEDEN 1991, 612 .
}

\section{I/1: Kötőtaggal és/vagy gyürükkel ellátott keskeny, nádlevél alakú lándzsacsúcsok}

A korai avar kopják közül a legjobban kutatott típus. Először a kutrigurokhoz, ${ }^{31}$ majd az előbbi elméletet cáfolva az avarok legkorábbi, honfoglaló generációjához kötötték a megjelenését. ${ }^{32}$ A tárggyal kapcsolatban felmerült a bizánci eredet lehetősége. ${ }^{33}$ Kovrig Ilona nyolc hasonló díszítésü példányt sorolt fel, ${ }^{34}$ Uta von Freeden a listát a környei 129. sír kopjájával egészítette ki. $^{35}$ Legutóbb Mechtild Schulze-Dörlamm állított össze leletlistát e típusról. ${ }^{36}$ Időközben a budakalász-dunaparti temető előkerülésével négy újabb példány vált ismertté. $^{37}$

A típushoz sorolható lándzsacsúcsok hossza 18 és $25 \mathrm{~cm}$ közötti. A penge keskeny, az élek párhuzamosan futnak, a csúcsnál ívelten találkoznak össze. A penge a nyaknál éles törésü vállal rendelkezik, a válltörés alatt kötőtagban folytatódik. A penge és a köpü hossza általában megegyezik, de bizonyos esetekben a penge hosszabb lehet, mint a köpü. ${ }^{38}$ A köpü nyitott, több esetben kis kapoccsal fogták össze. ${ }^{39}$

Az avar kori hasonló jellegü kopják elterjedése nagyjából a Duna folyó vonalát követi, elsősorban a Kelet-Dunántúlon jellemzőek. (3. kép)

\footnotetext{
${ }^{31}$ CSALLÁNY 1953, 133-137.

${ }^{32}$ KOVRIG 1955a, 40-41.

33 von FREEDEN 1991, 619-623.

${ }^{34}$ KOVRIG 1955a, 30-37.

${ }^{35}$ von FREEDEN 1991, 611.

${ }^{36}$ SCHULZE-DÖRLAMM 2006, 494-497.

${ }^{37}$ A 291., 705.; s 710. és a 715. sírok

lándzsacsúcsai. Ez úton szeretnék köszönetet mondani az ásatóknak Dr. Vida Tivadarnak és Dr. Pásztor Adriennek, hogy a temető leletanyagát felhasználhattam.

${ }^{38}$ Például Esztergom-Nagyhegy (HAMPEL 1900, 113; HAMPEL 1905, II. 346; KOVRIG 1955a, 36, X. tábla 6.) és Budakalász-Dunapart 291. sír.

${ }^{39}$ Ez alól kivételt képez a csákberényi temető 396. sírjából származó lándzsacsúcs, melynek köpüje zárt, a köpüszárnyakat egymásra kalapálták.
} 
Az I/1. típus több variánsra osztható, melyek között tipológiai fejlödés figyelhető meg. Az I/1.a variánshoz nagyméretü, finoman kidolgozott, profilált, sokszög átmetszetű kötőtagú példányok sorolhatók. Az I/1.b variánshoz tartozó lándzsacsúcsok az előzőnél kisebbek, kevésbé kidolgozottabbak, de rácsmintás gyürüvel és sokszög átmetszetü kötőtaggal rendelkező példányok. I/1.c variánshoz az elöbbieknél rosszabb kivitelü példányok tartoznak, melyeknél a kötőtagot már csak a penge alsó részén megjelenő enyhe perem jelzi.

Az I/1.a variáns minden jellegzetessége legtisztábban az esztergom-nagyhegyi példányon figyelhetö meg, mely facettált köpüjével, jól kidolgozott, profilált, hatszög átmetszetü kötőtagjával és jó minőségével kiemelkedőnek tekinthető. A facettált, sokszög átmetszetü köpü az itáliai példányok jellemző vonása, az esztergomi példány azonban rácsmintás gyürüjével, kötőtagjával (hiszen ez a Nocera-Umbra típusnál nem jellemző) és pengekiképzésével (hiányzik a NoceraUmbra típusnál meglevő párhuzamos, hosszanti árkolás a pengén,) nem sorolható az Ursula Koch-féle Nocera-Umbra típusba, ${ }^{40}$ ugyanakkor több közös vonást mutat a Steinheim-típussal, mellyel arányaiban, a penge formájával, kötőtagjával és facettált köpüjével rokonságot mutat. ${ }^{41}$

A Szentendre-Pannónia dülői lándzsacsúcs is ebbe a fejlődési szakaszba tartozik jól kidolgozott kötőtagjával, köpüjének bordázott díszítése ugyanakkor eltér az előzőektől. ${ }^{42}$

A fentiekben vázolt tipológiai sor részben időbeliséget is jelezhet, ugyanakkor azzal is számolhatunk, hogy részben egymással párhuzamosan is használtak hasonló jellegü lándzsacsúcsokat.

\footnotetext{
${ }^{40}$ KOCH 1968, 90. Liste 20/C. 256.

${ }^{41}$ KOCH 1968, ; FREEDEN 1991, 615, Abb. 15.

${ }^{42}$ PULSZKY 1874, 1-12; HAMPEL 1905. II. 343-345; III. Taf. 263-265; BÓNA 1982-83: 98-104; GARAM 1992, 138, 183, Taf. 11: 9.
}

A típushoz tartozó lándzsacsúcsokat Kovrig Ilona a kora avar kor első generációjára datálta. ${ }^{43}$ A típus datálását segíti a szentendrei lándzsacsúccsal együtt talált II. Iustinus (565-578) érem. ${ }^{44} \mathrm{~A}$ típusba tartozó lándzsacsúcsokat alemann területen a VI. század végére és a VII. század első harmadára datálják. ${ }^{45}$

I/2. Hosszú köpüjü, rövid nádlevél alakú pengéjü lándzsacsúcsok

Az I/2. típusú lándzsacsúcsok pengéje rövid, nagyjából $10 \mathrm{~cm}$ hosszú, ugyanakkor a köpüjük hossza jelentősen meghaladja a pengéét. Két változata ismert, egy jobb minőségü és díszített, alul füles gyürüvel megerősített nyitott köpüjü (I/2.a). ${ }^{46}$ A típus második változata (I/2.b) egyszerübb és díszítetlen. $\mathrm{E}$ variánsnál a nyitott és a zárt köpü egyaránt megtalálható.

I/3. A köpü és a penge hossza megegyezik

Az e típusba sorolható lándzsacsúcsok hossza 20 és $25 \mathrm{~cm}$ között ingadozik, pengéjük átmetszete rombusz alakú. $\mathrm{Az}$ I/3. a legelterjedtebb kora avar kori típusnak tekinthető. Nagy változatosság figyelhető meg a penge alakjában, a nyak átmérőjében és a köpű kialakításában, éppen e sokszínűség miatt nehéz a szabályszerüségek megállapítása.

A penge alakja alapján jól elváló variánst különíthetünk el, mely esetében a penge ívelt nádlevél alakú, oldalnézetben cukorsüvegre emlékeztet, nyaka erősen elkeskenyedik: I/3.a. A köpü kialakítása szerint egyszerübb a variánsok elkülönítése: megkülönböztethetünk nyitott köpüs (I/3.b), kapoccsal összefogott

\footnotetext{
${ }^{43}$ KOVRIG 1955a, 30-44.

${ }^{44}$ GARAM 1993, 141.

45 A schretzheimi temető 4. fázisa: KOCH 1977, 37.

${ }^{46}$ Ehhez a variánshoz sorolható a cikói temető 109 . sírjának (KISS - SOMOGYI 1984, 45, 80, 9. tábla 7.) és a pókaszepetki temető 332. sírjának lándzsája (SÓS - SALAMON 1995: 64-65, 67, Pl. XX/1 és Pl. LXXXI/4.).
} 
köpüszárnyú példányokat (I/3.c), zárt köpüs, egymásra hajtott köpüszárnyú lándzsacsúcsokat (I/3.d).

I/4. Hosszú nádlevél alakú pengéjü, rövid köpűjü lándzsacsúcsok

A típus már a VI. század első felében feltünik a Kárpát-medence germán lakosságának körében, megtalálhatók a langobard és a gepida sírokban ${ }^{47}$ egyaránt. A típus tehát biztosan nem az avarokkal kerül a Kárpát-medencébe.

$\mathrm{Az}$ avar kori hasonló pengéjü lándzsacsúcsok a fent említett típustól méretükben jelentősen eltérnek, hiszen jóval rövidebbek, mint a gyakran $30 \mathrm{~cm}-\mathrm{t}$ is meghaladó ,germán kopják”. Ursula Koch az Y10 típusba sorolta ezeket a 30$40 \mathrm{~cm}$ hosszú, keskeny pengéjü és zárt köpüjü lándzsacsúcsokat, melyeket szeriációjával az 5. délnémet fázisba (530555) datált. ${ }^{48}$ Kronológiájuk tehát megegyezik a Kárpát-medencei hasonló darabok datálásával, melyek az avar kor előtti időszakra keltezhetők.

II. Kihegyesedő, kúp alakú lándzsacsúcsok

A típus fö ismertetőjegye, hogy a penge és a köpü nem különül el egymástól, nem figyelhető meg nyakrész, hanem a penge a köpü folytatásaként értékelhető. A típus első leírója Garam Éva a tiszafüredi temető e típusba sorolható késő avar kori lándzsái kapcsán a szaltovói párhuzamokra hívta fel a figyelmet. ${ }^{49}$

A lándzsacsúcs általában kúp alakú, a penge átmetszete kör vagy négyzet alakú is lehet, a köpü erősen kiszélesedik, kiképzése általában nyitott, a köpüszárnyakat szorosan egymás mellé hajlították.

A típuson belül a penge átmetszete és vastagsága alapján választhatunk el variánsokat. A II/1. variáns nagyon

\footnotetext{
${ }^{47}$ Felsorolásukat lásd BÓNA 1978, 157-158.

${ }^{48}$ KOCH 2001, 62, 75.

${ }^{49}$ GARAM 1995, 350.
}

keskeny, négyzetes átmetszetü pengével jellemezhető. Párhuzamai a késő antik Invellinoból ismertek, ahol Volker Bierbrauer hajítógép lövedékeiként (Geschoßbolzen) értékelte a hasonló darabokat. ${ }^{50}$ Valószínü, hogy az avar kori Kárpát-medencében ezek a lándzsák döföfegyverként funkcionáltak. A II/2. variáns zömökebb, vastagabb pengéjü, melynek átmetszete lekerekített sarkú négyzet alakú.

A típus mindkét variánsa a kora avar kor legvégén jelenik meg, és a közép avar kortól kezdve vált általánossá a használata. (4. kép II.)

\section{Levél alakú (spitzovale) lándzsák}

A penge széles, levél alakú, legnagyobb szélessége a pengehossz középső harmadában található, átmetszete lapos, enyhén romboid vagy lencse alakú. A típusba tartozó lándzsacsúcsok hossza 25 és $40 \mathrm{~cm}$ közötti. Közös jellemzőjük, hogy a pengehossz a lándzsa teljes hosszának kétharmadát teszi ki. A nagy méretü pengéhez képest a köpü keskeny, átmérője nem éri el a $3 \mathrm{~cm}-t$, a köpühossz általában $10 \mathrm{~cm}$ körül mozog. A köpü legtöbbször zárt, ritkán megfigyelhető, hogy a köpüszárnyakat egymásra kalapálták. A típus elsősorban a Dunántúlon terjedt el. ${ }^{51}$

A típuson belül két variáns különíthető el a méreteik, elsősorban a köpü átmérője és a pengeszélesség alapján: nagy méretü zárt köpüjü levél alakú lándzsák (III/1) gyakori leletnek számítanak a Dunántúl avar kori temetöiben, összesen 38 ebbe a típusba tartozó lándzsalelet ismert. (5. kép)

A variánson belül külön figyelmet érdemel a Budakalász-dunaparti temető

\footnotetext{
${ }^{50}$ BIERBRAUER 1987, 170-171; II. Taf. 58: 110., Taf. 59: 1-5.

${ }^{51}$ Kivételek: Bugyi 21. sír (BÓNA 1957, 158, XLIII. tábla 17.); Baja, szórvány (ROEDIGER 1903a, 144-145; ROEDIGER 1903b, 272-276; HAMPEL 1905, II. 840-842. A lándzsa nem került múzeumba.
} 
437. sírjának lándzsája, melynek nyakát két bordával közrefogott nodussal díszítették. A lándzsa köpüjén különleges technológiai eljárást figyelhettünk meg: a köpüt vörösrézzel forrasztották össze. (6. kép) A vörösréz forrasz létét elektronmikroszkópos vizsgálat bizonyítja, a vörösréz funkciójára pedig egyértelmüen utalt, hogy a köpü belsejéből is sikerült mintát vennünk. ${ }^{52}$

A másik variánst a keskeny köpüjü, könnyü levél alakú lándzsák (III/2) jelentik, melyek hosszukban, arányaikban teljesen megegyeznek a III/1 variáns lándzsacsúcsaival, de azoknál finomabb kidolgozásúak, karcsúbbak, könnyebbek, karcsú nyakúak és köpüjük sokkal kisebb átméröjü (1,5 cm-es átlag). Hosszuk $30 \mathrm{~cm}$ között mozog, ugyanakkor pengeszélességük nem éri el a $3 \mathrm{~cm}$-t. A köpü átméröjének elsősorban a funkció meghatározásában van jelentősége, hiszen keskenyebb köpübe keskenyebb nyelet rakhatnak, és ez jelentősen befolyásolhatja a lándzsa teljesítőképességét is.

A típus másik érdekessége, hogy gyakran fordul elő párosával, ${ }^{53}$ sőt hármasával ${ }^{54}$ a kora avar kori sírokban. Két vagy több azonos típusú lándzsa sírba helyezése csak a Dunántúl kora avar kori temetőire jellemző.(7. kép) Két lándzsa sírba helyezése feltünik már a gepida

\footnotetext{
${ }^{52}$ Ez úton mondok köszönetet a Budapesti Müszaki Egyetem Fémtechnológiai Kutatócsoportjának, vezetőjének Dr. Dobránszky Jánosnak és a munkatársaknak, aki lehetővé tették a vizsgálatokat. ${ }^{53}$ Cikó B (vagyis 555. sír) (KISS - SOMOGYI 1984, 41. tábla 21-22.); Pécs-Köztemető 30. sír (KISS 1977, 96, XXXVIII. tábla); Várpalota-Unió homokbánya 210. sír (ERDÉLYI - NÉMETH 1969, 190.); Pókaszepetk 76. sír (SÓS SALAMON 1995, Pl. IX: 5-6.) és 360. sír (SÓS SALAMON 1995, Pl. XXII: 1.)

${ }^{54}$ Budakalász-Dunapart 1271. sír; Csákberény-Orondpuszta 44. sír (Székesfehérvár, IKM 10.217); Oroszlány-Borbálatelep (SÓS SALAMON 1995, 71. említi, publikálatlan); Pókaszepetk 88. sír (SÓS - SALAMON 1995, Pl. $\mathrm{X}: 1-3$.
}

korban is. ${ }^{55}$ Elképzelhető, hogy a keskeny köpüjü, könnyü, párosan vagy hármasával előforduló lándzsacsúcsokat hajítófegyverként használták. ${ }^{56}$

A nagy méretü levél alakú lándzsák általánosnak tekinthetők a németországi meroving kori temetőkben. Ottani kronológiájuk szerint a VI. század közepétől a VII. század elejéig datálhatóak. ${ }^{57}$

Használatuk a Kölked-Feketekapu A temetőben is elsősorban a korai időszakra jellemző, ${ }^{58}$ ugyanakkor a temető 107. sírjában előforduló ezüstből préselt pajzs alakú pont - vessző ornamentikás és növényi motívumos övveretek ${ }^{59}$ és a 259. sír Salona-Histria típusú csatja ${ }^{60}$ alapján a temetőben még a VII. század első felében is használták azt.

Hasonló a típus kronológiája a pókaszepetki temetöben is, ahol a használatának alsó határát a 76. sír gombos pajzsdudora jelzi, ${ }^{61}$ míg felső határát a 360 . sír szembeforduló állatalakokkal díszített bizánci tarsolycsatja mutatja. ${ }^{62}$

\footnotetext{
${ }^{55}$ Kisköre-Pap tanya 43. sír (BÓNA - NAGY 2002, 194; Taf. 29/6-7.). Az itt talált két lándzsa is a III/2. típusba sorolható.

${ }^{56}$ SÓS - SALAMON 1995, 72; ZÁSTEROVÁ $1971,78$.

${ }^{57}$ Schretzheim I-III. fázis: 545/550-590/600 (KOCH 1977, 37; 109-110.); délnémet 5. fázis: 530-600 (KOCH 2001, 62, 75.)

${ }^{58}$ Kölked-Feketekapu A-142. (KISS 1996, Taf. 41.) és 223. (KISS, 1996, Taf. 50.) sírokban pajzsos tüskéjü csattal (Schilddornschnalle) együtt fordulnak elö. E csattípus délnémet kronológiája szerint a 7. fázisba sorolhatók (KOCH 2001, 87). A jutasi 116. sírból származó magyarországi párhuzamát 608/609-ben vert Phokas érem keltezi (BÓNA 1982-83, 133.)

${ }^{59}$ KISS 1996, Taf. 34-35. Az övveretek kronológiáját lásd GARAM 2001, 119.

${ }^{60}$ KISS 1996,Taf. 57. A csatot VII. század közepinek tartotta UENZE 1966, 146., ugyanakkor GARAM 2001, 109. szerint e típusú csatok használata a VII. század első harmada után már nem folytatódik

${ }^{61}$ SÓS - SALAMON 1995, Pl. IX:1a-b., mely a délnémet 6-7. fázisra, vagyis a VI. század közepe és 600 közé datálható, lásd KOCH 2001, 86-87.

${ }^{62}$ SÓS - SALAMON 1995, Pl. XXII: 12., a csattípus kronológiájához lásd: GARAM 2001, 111-112.
} 


\section{Középbordás levél alakú lándzsák (Dorfmerkingen-típus)}

Bordával ellátott levél alakú lándzsák az egész avar kor folyamán előfordulnak, de különleges figyelmet érdemel egy viszonylag zárt kora avar kori csoport. E lándzsák közös jellemzője, hogy borda a köpü meghosszabbításának tekinthetö. Közös jellemzőjük, hogy köpüjük zárt. Kiss Attila a Kölked-Feketekapu A temetőről írt monográfiájában átvette Hübener Dorfmerkingen-típusnak elnevezését, és ezt a típust a VI. és VII. század fordulójára keltezte. ${ }^{63}$

A középbordás levél alakú lándzsák két típusra oszthatók, a IV/1. típusú lándzsacsúcsok pengéje levél alakú, sima, míg a IV/2. típusúak pengéje áttört. (8. kép) A IV/1. típus két variánsra osztható méret szerint. Külön figyelmet érdemel a Csepel-hárosi 5. sírból származó lándzsa, melynek köpüje négyszög átmetszetü. ${ }^{64}$

A IV/2. variánshoz tartozó középbordás levél alakú áttört pengéjü lándzsák közé jelenlegi ismereteim csak egy biztosan korai avar korra datált lelet tartozik: a Kölked-Feketekapu B temetőjének 82 . sírjából származó lándzsa, ${ }^{65}$ melynek pengéje félkör alakban áttört. Hasonló lándzsákat elsősorban Itáliából ismerünk. ${ }^{66}$ Az áttörés funkciójának meghatározására két elmélet született: 1 . zászlós lándzsa, ${ }^{67}$ 2. díszfegyver. ${ }^{68} \mathrm{~A}$ kölkedi darab

\footnotetext{
${ }^{63}$ KISS 1996, 234. Kiss Attila adatainak jó részét HÜBENER 1972, 193-211.-től vette át.

${ }^{64}$ NAGY 1998, 148, II. 108. Taf. 100/1. Hasonló köpükiképzés párhuzamai: Niederstotzingen 3a. sír (PAULSEN 1967, Taf. 17, 5.); Langenau, Kr. Ulm (HÜBENER 1972, Abb. 3: 2); Merdingen, Kr. Freiburg (GARSCHA 1970, Taf. 84, 16); Donaueschingen, szórvány (BUCHTA-HOLM 1996, Taf. 41: 56.); Weingarten 342. sír (ROTH THEUNE 1995, 100, Taf. 129: 4.)

${ }^{65}$ KISS 2001, 28, II. 42: Taf. 28/9.

${ }^{66}$ Gyüjtésükre és értelmezésükre lásd HESSEN 1971, Abb. 1: 1-4.; újabb példánya a Trezzo sull'Adda-i temetőből ismert: ROFFIA 1986, Taf. 6: 5 .

${ }^{67}$ von HESSEN 1971, 41; BÁLINT 2004, 364.

${ }^{68}$ von HESSEN 1971, 41.
}

egyértelmüen az itáliai párhuzamokhoz kötődik, és nincs köze az erdélyi hasonló jellegü csoporthoz. ${ }^{69}$

A bordával ellátott levél alakú lándzsák a VI. század végétől a VII. század első feléig jellemzőek. ${ }^{70}$ Megerősíti ezt a délnémet kronológia $^{71}$ és a Kölked-Feketekapu A temető 250. sírjából származó háromtagú bronz övgarnitúra is. $^{72}$

\section{Összegzés}

A kora avar kori lándzsacsúcsok formai osztályozása alapján bizonyos tipológiai folyamatok mutathatók ki. Egyrészt megfigyelhető az $\mathrm{I} / 1$ típuson belül a fokozatos egyszerüsödés, a kötőtag eltünése és a rácsmintás gyürük utánzása felé haladás. Kimutatható, hogy az elhegyesedő lándzsacsúcsok (III. formacsoport) csak a korszak legvégén jelennek meg. Előzményei közé tartozhatnak a hosszú köpüs, rövid pengéjü nádlevél alakú lándzsacsúcsok (I/2), de a III/2. típusnál felmerülhet a mediterrán eredet lehetősége is. ${ }^{73}$

A lándzsacsúcsok formai változatosságában e fegyvertípus széles körü kulturális kapcsolatrendszere is tükröződik. Az I. csoport lándzsacsúcsai megtalálhatók Belső-Ázsiában ${ }^{74}$ éppúgy, mint Kelet-Európában. ${ }^{75} \mathrm{Az} \quad$ I.

\footnotetext{
${ }^{69}$ Erről részletesebben HOREDT 1958, Fig. 9, Fig. 14., Fig. 17.; HOREDT 1968: 111.

${ }^{70}$ KISS 1996, 234.

${ }^{71}$ Ursula Koch 7. fázisa (580-600) lásd $\mathrm{KOCH}$ 2001, 63, 75.

${ }^{72}$ KISS 1996, Taf. 55. A hasonló övgarnitúrákat Németországban a 7. fázisra datálják: KOCH 2001, 87.

${ }^{73}$ BIERBRAUER 1987, 170-171.

${ }^{74}$ GAVRILOVA 1965, 55; CHUDJAKOV 1986, 106-107, 156-157. A rendkívül kis darabszám megnehezíti az értékelésüket, úgy tünik, hogy e területen elsősorban az I/2 típus terjedt el.

${ }^{75}$ A Kaukázus vidékén Dyrso (BÁLINT 1989: Abb. 14: 12, 13); Donyfars (KAMINSKY 1996, Fig. 8: 8.) Baltikum: KAZAKJAVIČJUS 1988, 4142, Ris. 15.: a szerző III. típusa nádlevél alakú, a penge jelentősen hosszabb, mint a köpü, $(=\mathrm{I} / 4)$ de a penge formája és a facettált köpü figyelemre méltó,
} 
formacsoporthoz tartozó lándzsacsúcsok azonban elöfordulnak bizánci környezetben az Észak-Balkánon is, ${ }^{76}$ a jelentős bizánci kulturális hatások alatt álló langobard Itáliában és a meroving kori Dél-Németországban is. ${ }^{77}$

A III. formacsoportba sorolható levél alakú lándzsacsúcsok leginkább a meroving kultúrkörre jellemzőek, ${ }^{78}$ de megtalálhatók az észak-balkáni koraközépkori bizánci erődök leletanyagában is. ${ }^{79}$ A középbordás levél alakú lándzsák (IV) is elsősorban a nyugati területekre jellemzőek, megtalálhatók Itáliától egészen a Rajna-vidékig. ${ }^{80}$

A Dunántúl a kora avar kori lándzsacsúcsok elterjedésében tapasztalható túlsúlya más tárgytípusok esetében is megfigyelhető, így nem egyedi jelenség. Hasonló sürüsödés érzékelhető a Dunántúl területén a VI. század végén és a VII. század első harmadában a bizánci leletek esetében. ${ }^{81}$ Bálint Csanád megállapítása, miszerint a nagyfokú dunántúli leletkoncentráció a tárgyak tipológiai változatosságával és jobb minőségével jár együtt, ${ }^{82}$ a lándzsákra is vonatkoztatható, hiszen egyedül ez az a terület, ahol mind a négy formacsoport, és valamennyi típus megtalálható. A jelenség lehetséges magyarázatai közé tartozhatnak a nagyobb népsürüség, a területet érő

datálásuk a Kárpát-medencei példányokéval párhuzamos: VI-VII. sz. A mai Ukrajna területén a VII. században szinte teljesen hiányoznak a kopják, lásd: KOMAR - SUCHOBOKOV 2000

összefoglalása, akik csak a VIII-X. századból tudtak lándzsacsúcsokat felmutatni.

${ }^{76}$ Sadovec: UENZE 1992, I. 445. II. Taf. 42: 1-4.

A formacsoport bizánci elterjedésének vizsgálatát jelentősen gátolja, hogy e területen nem temetkezésekből, hanem telepekről ismertek.

${ }^{77}$ Gyüjtésükre lásd FREEDEN 1991, 626-627;

SCHULZE-DÖRLAMM 2006: 494-496.

${ }^{78}$ HÜBENER 1977, 510-527; KOCH 2001, 61-63.

${ }^{79}$ Sadovec (UENZE 1992, I. 445; II. Taf. 42: 5-7.);

Caričin Grad (KONDIĆ - POPOVIĆ 1977, Tabl.

XVII: 96; BAVANT et al. 1990, 230, Fig. 165, Pl.

$\mathrm{XL}: 246$.

${ }^{80}$ HÜBENER 1972, 196, Abb. 2.: 90 példányt

gyüjtött össze.

${ }^{81}$ GARAM 2001, 194-195.

${ }^{82}$ BÁLINT 1993, 245; BÁLINT 1995, 317. intenzívebb nyugati és mediterrán hatások, a továbbélö késő antik és germán népesség anyagi kulturájának inspiráló hatása vagy közvetlenül továbbélő kézműves-műhelyek tevékenysége. ${ }^{83}$

Függelék

Leletlisták:

I/1.a:

1. Bácsújfalu (CSALLÁNY 1953, 134, XXXI. tábla 6.)

2. Esztergom-Nagyhegy (HAMPEL 1900, 113; HAMPEL 1905, II. 346; KOVRIG 1955a, 36, X. tábla 6.)

3. Szentendre-Pannónia dülő (PULSZKY 1874, 1-12; HAMPEL 1905, II. 343-345; III. Taf. 263-265; BÓNA 1982-83, 98-104; GARAM 1992, 138, Taf. 11: 9.)

4. Zámoly (MNM 61.202.1)

I/1.b:

1. Baja (ROEDIGER 1903a, 144-145; ROEDIGER 1903b, 272-276; HAMPEL 1905, II. 840-842; GUBICZA 1909, 27; KOVRIG 1955a: 36; KOVRIG 1955b: 171.)

2. Budakalász-Dunapart 291. sír

3. Budakalász-Dunapart 705. sír

4. Budakalász-Dunapart 710. sír

5. Budakalász-Dunapart 715. sír

6. Bugyi, szórvány (BÓNA 1957, 171, XL. tábla 1.)

7. Környe 129. sír (SALAMON - ERDÉLYI 1971, 27, 56, Taf. 22: 1., Taf. XVIII: 5.)

8. Szeged-Csengele (CSALLÁNY 1939, 9, VIII. tábla 1.)

9. Zámoly (KOVRIG 1955a, 37, X. tábla 4., XII. tábla 1; KOVRIG 1955b, 174, V. tábla 4, VII. tábla 1.)

I/1.c.:

1. Budapest IV. Káposztásmegyer-Váci országút (Megyer) (KOVRIG 1955a: 37; KOVRIG 1955b, 173; NAGY 1975, 198; NAGY 1998, I. 53-54; II. Taf. 46: 1.)

2. Csákberény-Orondpuszta 396. sír (IKM, Székesfehérvár 11.341)

3. Csepel-Háros (MNM 54.9.14)

4. Vörösmart (MNM FN 4/1910.1)

$\mathrm{I} / 2 . \mathrm{a}$
${ }^{83}$ A magyarázati lehetőségek legtöbbjét már
BÁLINT 1995, 316-317. leírta. 
1. Cikó 109. sír (KOVRIG 1955a, 34; KOVRIG 1955b, 34; 167-168; KISS SOMOGYI 1984, 9. tábla 7.)

2. Pókaszepetk 332. sír (SÓS - SALAMON 1995, 64-65, 67, 167, Pl. XX/1.; P1. LXXXI/4.)

$\mathrm{I} / 2 . \mathrm{b}$

1. Biharkeresztes-Lencséshát (MESTERHÁZY 1987, 222, 7. kép 3)

2. Budakalász-Dunapart 200. sír

3. Budakalász-Dunapart 728. sír

4. Kehida-TSz-major 2. sír (SZŐKE 2002, 77.)

5. Oroszlány 18. sír (SÓS 1958, 111. Abb. 22.)

6. Pókaszepetk 16. sír (SÓS - SALAMON 1995, 137, Fig. 21, Pl. I: 50, Pl. LXXXI: 3)

7. Pókaszepetk 82. sír (SÓS - SALAMON 1995, 145, Pl. IX: 1, Pl. LXXXI: 1)

8. Pókaszepetk 242. sír (SÓS - SALAMON 1995, 161, Pl. XVIII: 1, Pl. LXXXI: 5.)

9. Pókaszepetk 415. sír (SÓS - SALAMON 1995, 182, Pl. XXVII: 12, Pl. LXXXI: 6)

$\mathrm{I} / 3 . \mathrm{a}$

1. Budakalász-Dunapart 529. sír

2. Budakalász-Dunapart 832. sír

3. Budakalász-Dunapart 1077. sír

4. Budakalász-Dunapart 1235. sír

5. Szekszárd-Bogyiszlói út 356. sír (ROSNER 1999, Taf. 26: 9)

$\mathrm{I} / 3 . \mathrm{b}$

1. Andocs-Újhalastó 17. sír (GARAM 1973, 134, 6. ábra 40.)

2. Imrehegy (BALOGH 2002, 306, 11. kép 4.)

3. Szekszárd-Bogyiszlói út 126. sír (ROSNER 1999, Taf. 10: 1.)

4. Szegvár-Sápoldal (BÓNA 1979, 5, 3. kép 3)

5. Kölked-Feketekapu A-394. sír (KISS 1996, 110, Taf. 76: 3.)

$\mathrm{I} / 3 . \mathrm{c}$

1. Budakalász-Dunapart 1047. sír

2. Budakalász-Dunapart 1155. sír

3. Budakalász-Dunapart 1162. sír

I/3.d

1. Budakalász-Dunapart 55. sír

2. Budakalász-Dunapart 68. sír

3. Budakalász-Dunapart 719. sír
4. Budakalász-Dunapart 851. sír

5. Budakalász-Dunapart 930. sír

6. Budakalász-Dunapart 993. sír

7. Budakalász-Dunapart 1162. sír

8. Budakalász-Dunapart 1495. sír

9. Budakalász-Dunapart 1506. sír

10. Csolnok, szórvány (MNM 12/1951.6)

11. Csólyospálos (BALOGH 2002, 7. kép 6)

12. Kölked-Feketekapu A-211. sír (KISS 1996, 65, Taf. 49: 17.)

13. Szekszárd-Bogyiszlói út 350. sír (ROSNER 1999, Taf. 24: 15.)

14. Szekszárd-Bogyiszlói út 677. sír (ROSNER 1999, Taf. 45: 5)

II.

1. Budakalász-Dunapart 85. sír

2. Kölked-Feketekapu A-253. sír (KISS 1996, 74, Taf. 55: 2)

3. Kölked-Feketekapu A-422. sír (KISS 1996, 116, Taf. 79: 7.

4. Tiszaderzs 92. sír (MNM 26/1932.24)

5. Tiszaszentimre (MNM 61.164.1)

III/1.

1. Baja (Roediger 1903a, 144-145; Hampel 1905, II. 840-842.)

2. Bölcske 14. sír (SZELLE 1891, 241, 2. kép)

3. Budakalász-Dunapart 223. sír

4. Budakalász-Dunapart 260. sír

5. Budakalász-Dunapart 670. sír

6. Budakalász-Dunapart 680. sír

7. Budakalász-Dunapart 778. sír

8. Budakalász-Dunapart 1003. sír

9. Budakalász-Dunapart 1024. sír

10. Budakalász-Dunapart 1472. sír

11. Budapest-Szentendrei út (MNM 38/1935.63)

12. Bugyi 21. sír (BÓNA 1957, 158, XLIII. tábla 17.)

13. Gyód-Máriahegy 67. sír (KISS 1977, 41, Pl. IX: 5.)

14. Kölked-Feketekapu A-65. sír (KISS 1996, 33, Taf. 29/4.)

15. Kölked-Feketekapu A-142 (KISS 1996, 52, Taf. 41: 6)

16. Kölked-Feketekapu A-259. sír (KISS 1996, 76, Taf. 57/19)

17. Kölked-Feketekapu A-260. sír (KISS 1996, 76, Taf. 57: 20)

18. Kölked-Feketekapu A-386. sír (KISS 1996, 106, Taf. 75: 10)

19. Kölked-Feketekapu A-405. sír (KISS 1996, 113, Taf. 78: 6)

20. Kölked-Feketekapu A-406. sír (KISS 1996, 114, Taf. 78: 8) 
21. Kölked-Feketekapu A-474. sír (KISS 1996, 127, Taf. 86: 3)

22. Kölked-Feketekapu B-80. sír (KISS 2001, 26, Taf. 26: 2)

23. Kölked-Feketekapu B-135. sír (KISS 2001, 68, Taf. 42: 2)

24. Kölked-Feketekapu B-443. sír (KISS 2001, 142, Taf. 82: 4)

25. Pécs-Köztemető 4. sír (KISS 1977, 92, P1. XXXIV: 1)

26. Pécs-Köztemető 10. sír (KISS 1977, 94, Pl. XXXIV)

27. Pókaszepetk 12. sír (SÓS - SALAMON 1995, 137, Pl. I: 1, Pl. LXXXIII: 5)

28. Pókaszepetk 35. sír (SÓS - SALAMON 1995, 140, Pl. IV: 1, Pl. LXXXIV: 3)

29. Pókaszepetk 42. sír (SÓS - SALAMON 1995, 140, Pl. V: 7, P1. LXXXIII: 3)

30. Pókaszepetk 47. sír (SÓS - SALAMON 1995, 141, Pl. VI: 1)

31. Pókaszepetk 121. sír (SÓS - SALAMON 1995, 149, P1. XIII: 1, Pl. LXXXIV: 2)

32. Pókaszepetk 132. sír (SÓS - SALAMON 1995, 150, Pl. XIV: 4, Pl. LXXXIII: 2)

33. Pókaszepetk 180. sír (SÓS - SALAMON 1995, 154, P1. XVI: 2, Pl. LXXXIII: 4)

34. Üröm, szórvány (MNM 71/1906.2)

$\mathrm{III} / 2$.

1. Budakalász-Dunapart 1271. sír

2. Cikó B. sír (555. sír) (KOVRIG 1955a, 34; KOVRIG 1955b, 167-168; KISS -

SOMOGYI 1984, 66, 80, 41. tábla 21-22)

3. Csákberény 44. sír (IKM 10.217)

4. Csákberény 89. sír (IKM 10.249)

5. Előszállás-Bajcsihegy 200. sír (IKM 53.751)

6. Oroszlány-Borbálatelep (SÓS SALAMON 1995, 71.)

7. Pécs-Köztemető 30. sír (KISS 1977, 96, XXXVIII. tábla)
8. Pókaszepetk 76. sír (SÓS - SALAMON 1995, 143, Pl. IX: 5-6, Pl. Pl. LXXXII: 3-4)

9. Pókaszepetk 88. sír (SÓS - SALAMON 1995, 145, Pl. X: 1-3, Pl. LXXXII: 5-7)

10. Pókaszepetk 171. sír (SÓS - SALAMON 1995, 153, Pl. XIV: 1, Pl. LXXXII: 2)

11. Pókaszepetk 360. sír (SÓS - SALAMON 1995, 175, Pl. XXV: 1, Pl. LXXXI: 7)

12. Várpalota-Unió homokbánya 210. sír (ERDÉLYI - NÉMETH 1969, 190.)

IV/1.

1. Aradac-Mečka 72. sír (NAĐ 1959, 61, Tab. XVIII: 13)

2. Budakalász-Dunapart 1474. sír

3. Csepel (Szigetszentmiklós)-Háros 5. sír (NAGY 1998, 148, Taf. 100: 1)

4. Kölked-Feketekapu A-250. sír (KISS 1996, 73, Taf. 55: 17)

5. Környe, szórvány (SALAMON ERDÉLYI 1971, 30, Taf. 27: 46, Taf. XVIII: 3)

6. Környe, szórvány (SALAMON ERDÉLYI 1971, 30, Taf. 28: 5, Taf. XVIII: 7)

7. Környe, szórvány (SALAMON ERDÉLYI 1971, 30, Taf. 29: 2, Taf. XVIII: 6)

$\mathrm{IV} / 2$.

Kölked-Feketekapu B-82. sír (KISS 2001, 28, Taf. 28: 9)

\section{IRODALOM}

\section{BÁLINT Cs.}

1989 Die Archäologie der Steppe. Steppenvölker zwischen Volga und Donau vom 6. bis zum 10.

Jahrhundert. Wien - Köln

1993 Probleme der archäologischen Forschung zur awarischer Landnahme. In: Ausgewählte

Probleme europäischer Landnahmen des Früh- und Hochmittelalters. Methodische

Grundlagendiskussion im Grenzbereich zwischen Archäologie und Geschichte. (Hrsg.: Müller-

Wille, M. - Schneider, R.) Teil 1. Sigmaringen

1995 Kelet, a korai avarok és Bizánc kapcsolatai (Régészeti tanulmányok). MŐT 8. Szeged 
2004 A nagyszentmiklósi kincs. Régészeti tanulmányok. VAH. Budapest

BALOGH Cs.

2002 Régészeti adatok Bács-Kiskun megye területének kora avar kori történetéhez. Elömunkálatok a Duna-Tisza köze avar kori betelepülésének kérdéseihez. (Archäologische Angaben zur frühawarenzeitlichen Geschichte des Komitates Bács-Kiskun. Vorarbeiten zu den Problemen der Besiedlung des Donau-Theiß-Zwischenstromlandes in der Frühawarenzeit) MFMÉ - StudArch 8. 291-339.

BAVANT et al.

1990 Caričin Grad II. Le quartier sud-ouest de la ville haute. (éd.: Bavant, B., Kondić, V., Spieser, JM. Collection de l'École Française de Rome 75. Belgrade - Rome

BIERBRAUER, V.

1987 Invillino-Ibligo in Friaul. Die römische Siedlung und das spätantik-frühmittelalterliche Castrum. Münchner Beiträge Vor- und Frühgeschichte. 33. München

BÓNA I.

1957 Az ürbőpusztai avar temető. (Le cimetière avar de Ürbőpuszta). ArchÉrt 84. 155-174; XXX-XLIII. táblák

1978 Erdélyi gepidák - Tisza-menti gepidák (Régészeti kutatás-módszertani és leletértelmezési problémák) MTA II. Oszt. Közl. 27. 123-170.

1979 A Szegvár-sápoldali lovassír. Adatok a korai avar temetkezési szokásokhoz. (Das Reitergrab von Szegvár-Sápoldal. Beiträge zu den frühawarischen Bestattungssitten) ArchÉrt 106. 3-32.

1980 Studien zum frühawarischen Reitergrab von Szegvár. ActaArchHung 32, 31-95.

1982-83 A XIX. század nagy avar leletei (Die großen Awarenfunde des 19. Jahrhunderts). SzMMÉ, 81160.

BÓNA I. - NAGY M.

2002 Gepidische Gräberfelder am Theissgebiet. I. MonGermArch. Budapest BUCHTA-HOLM, S.

1996 Das alamannische Gräberfeld von Donaueschingen (Schwarzwald-Baar-Kreis). Forschungen und Berichte zur Vor- und Frühgeschichte in Baden-Württemberg 56. Stuttgart

CHUDJAKOV, Ju. S.

1986. Худяков, Ю. С. Вооружение средневевовых кочевников Южной Сибирии и Центральной Азии. Новосибирск

\section{CSALLÁNY D.}

1939 Kora-avarkori sírleletek (Grabfunde der Frühawarenzeit). FolArch 1-2. 121-180.

1953 A bácsújfalusi avarkori hamvasztásos lelet. Adatok a kuturgur-bolgárok (hunok) temetési szokásához és régészeti hagyatékához. ArchÉrt 80, 133-141.

DAIM, F.

1987 Das awarische Gräberfeld von Leobersdorf, NÖ. Studien zur Archäologie der Awaren 1. Wien 
DENNIS, G. T. - GAMILLSCHEG, E.

1981 Das Strategikon des Maurikios. Corpus Historiae Byzantinae 18. Wien

EGGERT, M. K. H.

2005 Prähistorische Archäologie. Konzepte und Methoden. Tübingen

ERDÉLYI I. - NÉMETH P.

1969 A várpalota-gimnáziumi avar temető. (A Bakonyi Múzeum avarkori leletanyagának ismertetése) (Awaren-Friedhof Várpalota-Gymnasium) I. VMMK 8, 167-198.

FREEDEN, U. von

1991 Awarische Funde in Süddeutschland? JRGZM 38, 593-627.

GARAM É.

1973 Avar temetők Andocson. (Avar cemeteries at Andocs) FolArch 24, 129-183

1992 Die münzdatierten Gräber der Awarenzeit. In: Daim, Falko (Hrsg.): Awarenforschungen I. Studien zur Archäologie der Awaren 4. Wien, 135-250.

1995 Das awarenzeitliche Gräberfeld von Tiszafüred. Cemeteries of the Avar Period (567-829) in Hungary 3.

2001 Funde byzantinischer Herkunft in der Awarenzeit vom Ende des 6. bis zum Ende des 7. Jahrhunderts. Monumenta Avarorum Archaeologica Vol. 5.

GARSCHA, F.

1971 Die Alemannen in Südbaden. Katalog der Grabfunde. Germanische Denkmäler der Völkerwanderungszeit 11.

HAMPEL J.

1900 Újabb hazai leletek az avar uralom korából. ArchÉrt 20, 107-125.

1905 Alterthümer des frühen Mittelalters in Ungarn I-III. Braunschweig

HESSEN, O. von

1971 Durchbrochene italisch-langobardische Lanzenspitze. FMS 5. 37-41.

HOREDT, K.

1958 Contributiii la istoria Transilvaniei în secolele IV-XIII. Bucureşti.

1968 Das Awarenproblem in Rumänien. ŠtZv AU SAV 16. 103-120.

HÜBENER, W.

1972 Der Fund von Eltdalen. Hedmark, Norwegen, in mitteleuropäischer Sicht. Ein Beitrag zur Bewaffnung der Merowingerzeit. Viking. 193-211.

1977 Waffennormen und Bewaffnungstypen der frühen Merowingerzeit. Fundberichte aus BadenWürttemberg 3. Stuttgart 510-527.

KAMINSKY, V. N.

1996 Early Medieval Weapons in the North-Caucasus - A Preliminary Review. Oxford Journal of Archaeology 15. 95-103.

KAZAKJAVIČJUS, V.

1988 Казакявичюс, В.: Оружие балтских племен II-VIII. веков на территории Литвы. Москва

KISS A.

1962 Az avarkori fegyverzet kérdéseihez. (publikálatlan szakdolgozat) ELTE Régészettudományi Intézet

1977 Avar Cemeteries in County Baranya. Cemeteries of the Avar Period (567-829) in Hungary 2. Budapest 
1996 Das awarenzeitlich gepidische Gräberfeld von Kölked-Feketekapu A. Monographien zur Frühgeschichte und Mittelalterarchäologie 2. Studien zur Archäologie der Awaren 5. Innsbruck

2001 Das awarenzeitliche Gräberfeld in Kölked-Feketekapu B. Monumenta Avarorum Archaeologica Vol. 6. I-II.

KISS G. - SOMOGYI P.

1984 Tolna megyei avar temetők. (Awarische Gräberfelder im Komitat Tolna) DissPann III/2.

KLEJN, L. S.

1983 Archaeological Typology. BAR International Series 153.

KOCH, U.

1968 Die Grabfunde der Merowingerzeit aus dem Donautal um Regensburg. Germanische Denkmäler der Völkerwanderungszeit. Serie A. Band X. Berlin

1977 Das Reihengräberfeld von Schretzheim. Teil 1. Germanische Denkmäler der Völkerwanderungszeit. Serie A. Band XIII. Berlin

2001 Das alamannisch-fränkische Gräberfeld bei Pleidelsheim. Forschungen und Berichte zur Vorund Frühgeschichte in Baden-Württemberg, 60. Stuttgart.

KOLIAS, T.

1988 Byzantinische Waffen. Ein Beitrag zur byzantinischen Waffenkunde von den Anfängen bis zur lateinischen Eroberung. Byzantina Vindobonensia XVII. Wien

KOMAR, A. V. - SUCHOBOKOV, O. V.

2000 Комар, А. В. - Сухобоков, О. В.: Вооружение и военное дело Хазарского каганата. Восточноевропейский археологический журнал 2 (3). Online folyóirat: http://archaeology.kiev.ua/journal/020300/komar_sukhobokov.htm

KONDIĆ, V. - POPOVIĆ, V.

1977 Caričin Grad. Site fortifié dans l’Illyricum byzantin. Belgrade

KOVRIG I.

1955a Adatok az avar megszállás kérdéséhez. ArchÉrt 82. 30-44.

1955b Contributions au probleme de l'occupation de la Hongrie par les Avars. ActaAH 6. 163-192.

MARTIN, M.

1989 Awarische und germanische Funde in Männergräbern von Linz-Zizlau und Környe. Ein Beitrag zur Chronologie der Awarenzeit. WMMÉ 15. 65-90

MESTERHÁZY K.

1987 Kora avar részleges lovastemetkezés Ártándról és Biharkeresztesröl. (Frühawarische partielle Pferdebestattungen aus Ártánd und Biharkeresztes) FolArch 38. 219-245.

NAĐ S̆.

1959 Nekropola kod Aradca iz ranog sredneg veka. (Die Nekropole bei Aradac aus dem frühen Mittelalter) RVM 8. 45-109.

NAGY T.

1975 Budapest története az öskortól az Árpád-kor végéig. A népvándorlás kora. In: Budapest története I. Szerk.: Gerevich László. Budapest, 185-216.

NAGY M.

1998 Awarenzeitliche Gräberfelder im Stadtgebiet von Budapest I-II. Monumenta Avarorum Archaeologica 2. Budapest.

PAULSEN, P.

1967 Alemannische Adelsgräber von Niederstotzingen (Kreis Heidenheim). Veröffentlichungen des Staatlichen Amtes für Denkmalpflege Stuttgart. Reihe A, Heft 12. 
PULSZKY F.

1874 A magyarországi avar leletekröl. Magyar Tudományos Akadémia, Értekezések a történelmi tudományok köréböl III. 7. 1-12.

ROEDIGER L.

1903a Ásatásainkról. BTTÉ XIX. 143-149.

1903b Koraközépkori lovas sírleletről Szeghegyen (Bács-Bodrog m.) ArchÉrt 23 (1903) 272-276.

ROFFIA, E.

1986 La necropoli longobarda di Trezzo sull’Adda. Milano

ROSNER Gy.

1999 Das awarenzeitliche Gräberfeld in Szekszárd-Bogyiszlói Strasse. Monumenta Avarorum Archaeologica Vol. 3. Budapest.

ROTH, H. - THEUNE, C.

1995 Das frühmittelalterliche Gräberfeld bei Weingarten (Kr. Ravensburg). 1.Forschungen und Berichte zur Vor- und Frühgeschichte in Baden-Württemberg. Stuttgart

SALAMON Á. - ERDÉLYI I.

1971 Das völkerwanderungszeitliche Gräberfeld von Környe. Studia Archaeologica V. Budapest

SCHULZE-DÖRLAMM, M.

2006 Awarische Einflüsse auf Bewaffnung und Kampftechnik des ostfränkischen Heeres in der Zeit um 600? In: Mode, M. - Tubach, J. (Hrsg.): Arms and Armour as Indicators of Cultural Transfer. Wiesbaden. 485-508.

SIEGMUND, F.

1999 Gürtel. MZ. RGA 13. 170-175.

SÓS Á.

1958 Das frühawarenzeitliche Gräberfeld von Oroszlány. FolArch X. 104-124.

Cs. SÓS Á. - SALAMON Á.

1995 Cemeteries of the Early Middle Ages (6th-9th Centuries A. D.) at Pókaszepetk. Budapest

SZELLE Zs.

1891 Régészeti ásatások a bölcskei népvándorláskori temetőben. ArchÉrt 11. 239-249.

SZÖKE B. M.

2002 Avar kori központok a határ mentén. IN: Központok a Zala mentén. A Göcseji Múzeum állandó kiállítása. Katalógus. (szerk.: Vándor László). Zalaegerszeg

TOMKA P.

1973 A környei avar kori temetö történeti értékeléséhez. AT 20. 227-231.

UENZE, $\mathrm{S}$.

1966 Schnallen mit Riemenschlaufe aus dem 6. und 7. Jh. Bayerische Vorgeschichtsblätter 31. 142181.

1992 Die spätantiken Befestigungen von Sadovec (Bulgarien). Ergebnisse der deutsch-bulgarischösterreichischen Ausgrabungen 1934-1937. Münchner Beiträge zur Vor- und Frühgeschichte. Band 43. München

VIDA T.

1999 Die awarenzeitliche Keramik I. VarArchHung VIII. Budapest

WERNER, J. 
1971 Nomadische Gürtel bei Persern, Byzantinern und Langobarden. In: La civiltá di Langobardi in Europa. Kongress Rom. 109-139.

\section{ZÁSTEROVÁ, B.}

1971 Les Avares et les Slaves dans la Tactique de Maurice. Prága

\section{DIE TYPOLOGIE DER FRÜHAWARENZEITLICHEN LANZENSPITZEN}

Die vorliegende Arbeit ist eine Klassifikation und eine typologische Analyse der frühawarenzeitlichen Lanzenspitzen. Die Grundlagen dieser Klassifikation sind die sogenannte Kombinationstypen. Die Forme des Blattes wurde als Hauptmerkmal betrachtet, die Proportion des Blattlanges und Tüllenlanges, die Maße, die Gestaltung der Tülle und die Verzierung sind die sekundäre Merkmalen.

Anhand der Forme des Blattes kann man vier Formengruppe unterscheiden: I. schmales, schilfblattförmiges Blatt, II. konisches, III. spitzovales und IV. spitzovales Blatt mit Mittelrippe (d. h. übergehende Tülle).

Die Formengruppe I. wurde auf Grund der Proportionen und Verzierungen $\mathrm{zu}$ vier Typen geteilt: I/1. Lanzenspitzen mit schmales, schilfblattförmiges Blatt mit Zwischenfutter und die Tüllen verzierenden Banden (mit Gitter- oder Rippenmuster); I/2. die Tülle ist länger als das Blatt $\mathrm{I} / 3$. die Proportion des Blattes und der Tülle ist zirka 1: 1; I/4. das Blatt is länger als die Tülle. Das Typ I/1 ist auf 3 Varianten unterteilbar: I/1.a-c; zwischen denen man eine typologische Entwicklung beobachten kann. Die Variante I/1.a ist mit grosse Maßen, gute Qualität, vielkantiges Zwischenfutter und manchmal fazettierte Tülle charakterisiert. Die Exemplaren der Variante I/1.b sind schon kleiner und viel einfältiger, während die Lanzenspitzen der Variante I/1.c schon als schlichte Kopien der I/1.a Variante betrachtbar sind.

Die Lanzenspitzen des Typs I/4 sind nur aus den langobardischen und gepidischen Gräberfeldern bekannt, während die Typen $I / 2$ und $I / 4$ in den frühawarenzeitlichen Gräberfeldern gut verbreitet sind.
Die Formengruppe II. ist sehr selten in der Frühawarenzeit, weil es am Ende dieser Periode erscheint. Die Lanzenspitzen der Formengruppe III, d. h. die spitzovale Lanzenspitzen sind schon viel häufiger, aber ihre Verbreitungsgebiet beschränkt sich nur auf Transdanubien. Diese Gruppe hat zwei Typen: die Lanzenspitzen des Typs III/1 sind grösser und breiter, wie die von Typ III/2. Die letzteren Lanzenspitzen auftreten häufig paarweise, in einigen Fällen sogar Dreier, was vielleicht auf ihre Funktion als Wurfwaffe anweist. Diese Formengruppe hat enge Beziehungen mit den Lanzenspitzen der merowingerzeitlichen Alemannia und Bayern.

Zur Formengruppe IV gehören die Lanzenspitzen des sgn. Dorfmerkingen-Typs (IV/1) und die Lanzenspitzen mit durchbrochenen Blatt (IV/2). Das Typ IV/1 hat gute merowingerzeitliche Analogien aus Süddeutschland und Italien, während die Paralellen des Typs IV/2 bisher nur aus langobardenzeitlichen Italien bekannt sind.

In der Verbreitung der Lanzenspitzen kann man eine überwiegende Dominanz von Pannonien beobachten. Das bedeutet nicht nur Anzahl, sondern auch Formenvielfalt und typologische Wechselspiel. Es ist sehr auffallend dass, alle Formengruppe und Typen sich nur in Transdanubien befindet. Es gibt mehrere Erklärungsmöglichkeiten dafür: z. B. grössere Bevölkerungsdichte, die intensivere westliche und mediterrane kulturelle Kontakte dieses Bereichs, die Inspiration der materiellen Kultur der weiterlebenden spätantiken und germanen Bevölkerung oder die Tätigkeit einiger direkten weiterlebenden Handwerker-Werkstätten.

\section{Rezümé fordítása: A KORA AVAR KORI LÁNDZSACSÚCSOK TIPOLÓGIÁJA}

Az alábbi munka a kora avar kori lándzsacsúcsok osztályozása és tipológiai elemzése. A felosztás alapját a kombinációs típusok képezik. A penge formáját tekintem fö kritériumnak, és a penge- és köpühossz arányát, a méretet, a köpü kiképzését és a díszítést másodlagos kritériumnak.
A penge formája alapján négy formacsoportot lehet elkülöníteni: I. keskeny, nádlevél alakú penge, II. kúpos, kihegyesedő, III. levél alakú, IV. levél alakú középbordás.

$\mathrm{Az}$ I. csoportot az arányok és a díszítés alapján négy típusba osztottam, I/1. kötőtagagl és/vagy a köpüt díszítő (rácsmintás vagy bordadíszes 
pántokkal díszített lándzsacsúcsok; I/2. a köpü hosszabb, mint a penge, $\mathrm{I} / 3$. a köpü- és a pengehossz aránya nagyjából $1: 1, \mathrm{I} / 4$. a penge hosszabb, mint a köpü. Az I/1 típus három variánsra osztható: I/1.a-c; melyek között tipológiai fejlödés figyelhető meg. Az I/1.a variáns nagy mérettel, jó minőséggel, sokszög átmetszetü kötőtagjgal és facettált köpüvel jellemezhető. Az I/1.b variáns példányai már sokkal kisebbek, és egyszerübb kivitelüek, míg az I/1.c variáns lándzsacsúcsai már az előbbi variánsok egyszerü utánzatainak tekinthetők.

Az I/4 típus lándzsacsúcsai csak a Kárpátmedence langobard és gepida temetőiben ismertek, míg az I/2 és I/3 típusok széles körben elterjedtek az avar kori Kárpát-medencében.

A II. formacsoport nagyon ritka a kora avar korban, mert az csak a periódus végén jelenik meg. A III. formacsoport lándzsái, tehát a levél alakú lándzsák sokkal gyakoribbak, de az elterjedési területük csak a Dunántúlra korlátozódik. Ez a csoport két típusra osztható: a III/1 típus lándzsái nagyobbak és szélesebbek, mint a III/2 típushoz tartozó példányok. Ez utóbbi típus lándzsacsúcsai gyakran párosával, sőt néhány esetben hármasával kerülnek elő, ami talán hajítófegyver funkciójukra is utalhat. Ez a formacsoport szoros formai kapcsolatokat mutat Alemannia és Bajorország lándzsacsúcsaival.

A IV. formacsoporthoz tartoznak az ún. Dorfmerkingen-típusú (IV/1) és az áttört pengéjü (IV/2) lándzsacsúcsok. A IV/1-típus jó meroving kori analógiákkal rendelkezik Dél-Németországból és Itáliából, míg a IV/2 típus párhuzamai mindeddig csak a langobard Itáliából ismertek.

A lándzsacsúcsok elterjedésében Pannónia jelentős túlsúlya figyelhető meg. Ez nemcsak a darabszámra, hanem a formai változatosságra is vonatkozik. Nagyon feltünő, hogy az összes formacsoport és típus csak a Dunántúlon található meg együtt. Több magyarázati lehetőség is kínálkozik erre, pl. a nagyobb népsürüség, az intenzívebb nyugati és mediterrán kulturális hatások, a továbbélő későantik és germán lakosság anyagi kultúrájának inspirációja vagy egyes közvetlenül továbbélő mühelyek tevékenysége.

\section{Képaláírások}

1. kép. A lándzsacsúcsok részei és méretadatai - Abb. 1. Die Teilen und Massen der Lanzenspitzen

2. kép. A keskeny nádlevél alakú lándzsacsúcsok osztályozása - Abb. 2. Die Klassifikation der schmalen, schilfblattförmigen Lanzenspitzen

3. kép. Az I/1 típus elterjedése a Kárpát-medencében. - Abb. 3. Die Verbreitung des Typs I/1 im Karpetenbecken. 1. Bácsújfalu, 2. Baja, 3. Budakalász-Dunapart 291., 705., 710. és 715. sírok, 4. BugyiÜrbőpuszta, 5. Csákberény-Oromdülő 396. sír, 6. Esztergom-Nagyhegy, 7. Környe 129. sír, 8. SzegedCsengele, 9. Zámoly (A szakirodalmi adatokat lásd a I/1a-c leletlistáknál.)

4. kép. A II-IV. formacsoportok lándzsacsúcsainak osztályozása - Abb. 4. Die Klassifikation der Lanzenspitzen der Gruppen II-IV.

5. kép. A III/1 típus elterjedése a Kárpát-medencében - Abb. 5. Die Verbreitung des Typs III/1. im Karpatenbecken. 1. Baja, 2. Bölcske 14. sír, 3. Budakalász-Dunapart 223., 260., 670., 680., 778., 1003,. 1024. és 1472. sírok, 4. Budapest-Szentendrei út, 5. Bugyi 21. sír, 6. Gyód-Máriahegy, 7. Kölked-Feketekapu A-65., 142., 259., 260., 386., 405., 406., 474. és B-80., 135., 443. sírok, 8. Pécs-Köztemető 4., és 10. sírok, 9. Pókaszepetk 12., 35., 42. 47., 121., 132. és 180. sírok. 10. Üröm szórvány

6. kép. A Budakalász-dunaparti 437. sír lándzsája és részletfotói - Die Lanzenspitze des Grabes 437. von Budakalász-Dunapart und ihre Makrofotographien.

7. kép. A III/2. típus elterjedése a Kárpát-medencében . • Három lándzsa egy sírban, • két lándzsa egy sírban, $\boldsymbol{\Delta}$ egy lándzsa egy sírban - Abb. 7. Die Verbreitung des Typs III/2. im Karpatenbecken. • Drei Lanzenspitzen in einem Grab, zwei Lanzenspitzen in einem Grab, $\mathbf{\Delta}$ ein Lanzenspitze in einem Grab. 1. BudakalászDunapart 1271. sír, 2. Cikó B. sír (555. sír), 3. Csákberény-Orondpuszta 44. és 89. sír, 4. Előszállás-Bajcsihegy 200. sír, 5. Oroszlány-Borbálatelep, 6. Pécs-Köztemető 30. sír, 7. Pókaszepetk 88., 171., 360. sírok, 8. Várpalota-Unió homokbánya 210. sír.

8. kép. A IV. csoport elterjedése a Kárpát-medencében. • Dorfmerkingen-típus, 匹 áttört pengéjü. - Abb. 7. Die Verbreitung der Gruppe IV. im Karpatenbecken. • Dorfmerkingen-Typ, a mit durchbrochenes Blatt. 1. Aradac- 
Mečka 72. sír, 2. Budakalász-Dunapart 1474. sír, 3. Budapest XXI. Csepel-Háros 5. sír, 4. Kölked-Feketekapu A-250. és B-82. sírok, 5. Környe 